\title{
RESEARCH
}

\section{Renewable Electricity Production and Sustainability of the National and Regional Power Systems of Kazakhstan}

\author{
Nazym Temirgaliyeva ${ }^{1}$ and Madina Junussova ${ }^{2}$ \\ 1 Energy and Environmental Management, Europa-University in Flensburg, DE \\ 2 Institute of Public Policy and Administration, University of Central Asia, KZ, KG, TJ \\ Corresponding author: Madina Junussova (madina.junussova@ucentralasia.org)
}

The government of Kazakhstan is following many other national governments in promoting the development of renewable energy generation through adjustment of the policy environment and investment incentives. The government has started to invest in the construction of wind-, solar- and hydro-energy producing stations, some of which already operate in different regions of Kazakhstan. This paper aims to address the local challenges of the transition to renewable electric energy generation in the Almaty region of Kazakhstan. The authors examine regional challenges associated with introducing renewable energy production, with a focus on the energy market, the regional grid and energy management practices. The findings show that the development of renewable energy in the Almaty region is complicated by the absence of decentralized consumption options, the unreadiness of the regional grid and traditional power stations to accept renewable energy and the centralized old-fashioned management of the energy system. Instead of the expected increase of cheap energy for the private sector, there is an increasing technological and financial burden on traditional energy producers. The findings of the study raise serious research questions for further exploration: what is the real cost of clean energy production for regions of Kazakhstan, and why does public investment in support of renewable energy production not consider the implications of increasing the efficiency of traditional energy production and modernizing regional energy grids?

Keywords: renewable energy; regional development; energy policy; Kazakhstan; grid integration; energy market; energy management

\section{Introduction}

The United Nations Conference on Sustainable Energy 'RIO+20' and the launch of the 'Sustainable Energy for All' initiative opened a new stage in the transition to sustainable energy development for many countries. In 2018, wind and solar power plants accounted 
for $88 \%$ of the electricity generation capacity of the European Union (EU) (Kazenergy, 2019, p. 136). The new EU 2030 Directive aims to fulfil at least 32\% of the total energy demand using renewable energy ${ }^{1}$ by 2030 (EU, 2020). EU renewable energy policy highlights the importance of the stability of electricity supply systems and integrated public investments, aiming to adjust existing energy systems to new alternative power inputs. According to International Energy Agency (IEA 2015) estimates, by 2035 a total investment of around EUR 480 billion will be needed to develop the European power distribution network to prepare it to accept renewable energy. In 2017, China became the global leader in investments into renewable energy development, spending USD 126.6 billion, which accounts for $45 \%$ of the USD 279.8 billion invested into all renewable energy worldwide (Frankfurt School of Finance and Management 2018). Lin and Li (2015) calculated that, by 2020, China will incur expenses for guaranteed renewable energy purchases and the implementation of the measures required for grid integration and power system balancing (Lin \& Li, 2015).

The readiness of the government of Kazakhstan to push the country towards sustainable energy production was demonstrated by hosting of the EXPO-2017 'Energy of the Future' in Nur-Sultan and enactment of a Sustainable Energy Strategy. The idea of transitioning Kazakhstan to a 'green economy' was one of the first strategic steps towards the development of renewable energy production in the country (Presidential Executive Decree of the Republic of Kazakhstan No. 577, 2013). The government of Kazakhstan chose renewable energy development as one of the main instruments of the country's climate policy. The Kazakhstan government aims to achieve a $6 \%$ share of renewable energy in total electricity production by 2025 (Presidential Executive Decree of the Republic of Kazakhstan No. 636, 2018). In 2020, new solar, wind and small hydropower plants account for about $2.4 \%$ of the total installed capacity (Kazenergy, 2019). The government attracted USD 110 million of investments from the Green Climate Fund to support renewable energy projects under the European Bank for Reconstruction and Development (EBRD) (Green Climate Fund, 2020). National government policy mainly aims to increase the number of new renewable power plants by lowering initial investment costs and guaranteeing electricity purchases at fixed rates. However, little attention is being focused on required upgrades of the power system inherited from the Soviet era that for many years served traditional power plants. ${ }^{2}$

In the case of Kazakhstan, renewable electricity production cannot fully replace traditional hydrocarbon-based energy generation in the foreseeable future due to the country's economic and technological development challenges. Under the current conditions of compulsory renewable energy integration into the centralized grid, traditional power plants play a vital role in balancing volatile generation from renewable energy sources dependent upon weather conditions. Traditional thermal power plants produce both electricity and heating (hot water). At the same time, the development of renewable electricity generation has great potential to stimulate the economic development of the southern regions of Kazakhstan, which often experience energy deficits and are dependent upon imported energy from neighbouring countries including Kyrgyzstan. However, to make renewable energy production beneficial for regional development, it is important to carry out in-depth investigations of how best to integrate renewable energy sources into existing national and regional power systems. This paper aims to assess some of the key challenges associated with the implementation of policy supporting the development of renewable energy sources in Kazakhstan. The Almaty region is used as a case study, since it has the largest number of operating solar, wind

\footnotetext{
${ }^{1}$ In this paper, renewable energy mainly refers to wind-, solar- and hydro-energy.

2 In this paper, traditional power plants refer to electricity generating power plants operating with non-renewable resources such as coal.
} 
and hydropower stations in Kazakhstan, yet still experiences electricity shortages. Our findings show that the established conditions for integrating renewable energy into the national energy market and grid system should be reassessed in terms of their impact on other energy producers and the long-term sustainability of the national and regional power systems.

\section{Literature Review}

Internationally, renewable energy is expected to facilitate a wide range of environmental, social and economic benefits (see, for example, Sadorsky, 2012; Omri, 2014; Ruggiero \& Lehkonen, 2017). Kazakhstan, like other countries with promising renewable energy potential, has begun to be the focus of international and national academic discussions on renewables. Researchers have analysed its potential for the development of renewable energy sources including solar energy (Terehovics et al. 2017), wind energy (Akhmetov et al. 2011; Yashkov et al. 2015), hydro-energy (Eshchanov et al. 2019) and bioenergy (Koshim et al. 2018). Scholars have modelled the possible development of energy generation in the country and suggested the best ways to achieve the highest possible levels of energy efficiency (Sarbassov et al. 2013; Aldayarov et al. 2017). There are studies examining country-level transitions to renewables focusing on energy security (e.g., Mouraviev \& Koulouri 2018). Other researchers have investigated renewable energy's potential benefits for agriculture and in rural areas generally (Abayev et al. 2018; Bolyssov et al. 2019). In many cases, these papers advocate better governmental measures to support renewable energy production (Karatayev \& Clarke 2016). However, there are relatively few studies assessing policy drivers and existing institutional and infrastructural barriers (Karatayev et al. 2016).

Recently, Kazakh scholars have begun to engage in energy policy debates around the changing energy market conditions driven by fixed electricity tariffs. Research conducted into feedin tariffs and auction mechanisms emphasizes the positive effect of these legal actions on renewable energy projects in Kazakhstan (Tasmaganbetov et al. 2020). Teleuyev et al. (2017) examined fixed tariff practices, paying attention to drawbacks including the growing national financial burden caused by the guaranteed purchase of electricity generated by renewable energy producers. Taking the position of practitioners, representatives of national companies who are responsible for operating the national power system argue that fast growth in renewable energy production without adequate preparation can bring about considerable long-term costs associated with disruptions to the electricity supply (Mukatov \& Khabibullin 2018; Kazenergy 2019). Energy experts have been calling for better planning of integrating renewables and comprehensive economic analyses of their effect on the overall operation of the national power system.

As the experience of European and Middle Eastern countries shows, to minimize the extra costs related to disruptions of the generation and supply of electricity, more attention should be paid to the risks associated with the integration of renewables into national and regional power systems (Gastli \& Armendáriz 2013; IEA 2015). In addition to direct public investmentrelated costs, there are other economic and technological implications, including indirect costs related to the adjustment of traditional regional energy systems to renewable energy inputs (Alsaif, 2017; Koch-Ciobotaru et al. 2015; World Energy Council, 2016). There is a shortage of studies assessing how renewable energy production impacts the reliability and sustainability of the national and regional power systems of Kazakhstan. Up to now, the renewable energy potential of Kazakhstan has been mainly discussed without much attention to the traditional power generators that continue to play a key role in balancing the output of national and regional power systems. This paper aims to fill this gap in the national literature by addressing the impact of renewable energy policy on the overall sustainability of national and regional power systems in Kazakhstan. 


\section{Methodology}

We examined the integration of renewable energy into Kazakhstan's national and regional power systems based primarily on a literature review and analysis of national legislation, reports and data provided by the government and energy companies (see Table 1). The literature review findings were cross-checked by conducting interviews with civil servants, energy experts responsible for the planning and management of energy projects and representatives

Table 1: The list of studied documents.

No. Name of the document

Study periods

\section{National laws and rules}

1 Law on Natural Monopolies and Regulated Markets No.272

February 2018 (1998, July 9).

2 Law on Support for the Use of Renewable Energy Sources No.165 IV February 2018 (2009, July 4)

3 Law of the Republic of Kazakhstan on Natural Monopolies No. 204-VI (2018, December 27)

4 Rules for Determining Fixed Tariffs and Marginal Auction Prices, Government Resolution of the Republic of Kazakhstan No.271

(2014, March 27)

5 Grid Rules, Order of the Minister of Energy of the Republic of Kazakhstan No. 210 (2014, December 18)

$6 \quad$ New Rules for Determining Fixed Tariffs and Marginal Auction Prices, Government Resolution of the Republic of Kazakhstan No.925 (2017, December 29)

\section{National and regional plans and programs}

7 Concept for the Transition of the Republic of Kazakhstan to the

March 2018 'Green Economy', Presidential Executive Decree of the Republic of Kazakhstan No.577 (2013, May 30)

8 Regional Development Programme 2020, Government Resolution of the Republic of Kazakhstan No.728 (2014, June 28)

January 2019

February 2018

February 2018

February 2018

March 2018

9 Approved Electricity and Capacity Balance Forecasts for 2019-2025, March 2018 Order of the Minister of Energy of the Republic of Kazakhstan No. 478 (2016, November 7)

10 Strategic Development Plan of the Republic of Kazakhstan until

April 2018 2025, Presidential Executive Decree of the Republic of Kazakhstan No.636 (2018, February 15)

11 Program for Development of Renewable Energy Sources in the Almaty Region for 2017-2025

April 2018

\section{Companies' reports and strategies}

12 The National Energy Reports of the Kazakhstan Association of Oil, Gas and Energy Sector Organizations 'Kazenergy' 2016, 2017, 2018 and 2019

13 Kazakhstan Operator of the Market of Electric Energy and Power KEGOC's Development Strategy 2018-2028

February 2018 and

January 2020

January 2019 


\section{Statistical data and special datasets}

14 The auction results for 2018 and 2019 reported by the Kazakhstan Operator of the Market of Electric Energy and Power 'KOREM'

January 2019 and January 2020

15 Statistics on renewables provided by the Ministry of Energy of the Republic of Kazakhstan

16 Data on electricity tariffs approved by the Committee for Regulation of Natural Monopolies, Protection of Competition and Consumer Rights

17 Information on existing renewable energy facilities in Almaty region January 2020 provided by the Department of Energy and Housing and Communal Services of Almaty Region

Source: Developed by the authors.

Table 2: The list of study participants.

\begin{tabular}{|c|c|c|c|c|c|}
\hline No & $\begin{array}{l}\text { Interview } \\
\text { participants }\end{array}$ & Affiliation & $\begin{array}{l}\text { Number } \\
\text { of people }\end{array}$ & Location & $\begin{array}{l}\text { Interview } \\
\text { periods }\end{array}$ \\
\hline 1 & Civil servants & $\begin{array}{l}\text { Ministry of Energy of the } \\
\text { Republic of Kazakhstan }\end{array}$ & 3 & $\begin{array}{l}\text { Nur-Sultan } \\
\text { city }\end{array}$ & $\begin{array}{l}\text { February } \\
2019\end{array}$ \\
\hline 2 & Civil servants & $\begin{array}{l}\text { Local authorities of Almaty } \\
\text { Region }\end{array}$ & 3 & $\begin{array}{l}\text { Taldykorgan } \\
\text { town }\end{array}$ & August 2019 \\
\hline 3 & Civil servants & $\begin{array}{l}\text { Local authorities of } \\
\text { Kapshagay town }\end{array}$ & 3 & $\begin{array}{l}\text { Kapshagay } \\
\text { town }\end{array}$ & August 2018 \\
\hline 4 & Entrepreneurs & $\begin{array}{l}\text { The Almaty region branch } \\
\text { of the National Chamber of } \\
\text { Entrepreneurs ATAMEKEN }\end{array}$ & 5 & $\begin{array}{l}\text { Taldykorgan } \\
\text { town }\end{array}$ & May 2018 \\
\hline 5 & $\begin{array}{l}\text { National } \\
\text { energy experts }\end{array}$ & $\begin{array}{l}\text { Satpaev University, } \\
\text { Kazakh-German University }\end{array}$ & 2 & Almaty city & May 2018 \\
\hline 6 & $\begin{array}{l}\text { National } \\
\text { energy experts }\end{array}$ & KEGOC, Samruk Energy & 2 & $\begin{array}{l}\text { Nur-Sultan } \\
\text { city }\end{array}$ & $\begin{array}{l}\text { February } \\
2019\end{array}$ \\
\hline 7 & $\begin{array}{l}\text { Local energy } \\
\text { experts }\end{array}$ & $\begin{array}{l}\text { Regional electricity grid } \\
\text { companies, energy producing } \\
\text { organizations, regional energy } \\
\text { transmission organizations }\end{array}$ & 8 & $\begin{array}{l}\text { Taldykorgan } \\
\text { town }\end{array}$ & $\begin{array}{l}\text { February and } \\
\text { April } 2019\end{array}$ \\
\hline 8 & Managers & $\begin{array}{l}\text { Traditional and renewable } \\
\text { power plants operating in the } \\
\text { Almaty region }\end{array}$ & 4 & $\begin{array}{l}\text { Taldykorgan } \\
\text { town }\end{array}$ & $\begin{array}{l}\text { February } \\
2019\end{array}$ \\
\hline
\end{tabular}

Source: Developed by the authors.

of public and private companies running renewable and traditional power plants (see Table 2). Our selection of focus areas was based on both the findings of the literature review and our interviews with national and local industry experts. All interviewees emphasized that the sustainability of national and regional power systems is highly dependent on the institutional conditions created to support the reliable functioning of the energy market, 
grid system and energy management. We integrated the results of the literature review and interviews based on practical field knowledge obtained through our own participation in the planning and design of regional energy projects. The paper does not include an assessment of bioenergy potential, because of its very low input into the current electric power production of Kazakhstan. Further, due to the inaccessibility of regional financial data on public and private investments in the energy sector, and technical data on important characteristics of energy generation, distribution and consumption, we were unable to carry out a comprehensive quantitative analysis of the possible costs associated with the integration of renewables.

\section{The Regional Electric Power System of Kazakhstan and the Case of the Almaty Region}

Kazakhstan's energy system consists of three energy zones, North, South and West (see Figure 1). The North and West zones maintain technological links with the Russian power system. The South zone is connected to Central Asian systems. The North zone currently has a 14.8 billion kWh (Kilowatt-hour) generation surplus and supplies $72.6 \%$ of all Kazakhstan's non-renewable energy (Kazenergy 2019, p. 115). From 2017 to 2018, power production increased in the North (5\%) and West (8\%), but decreased in the South by $4.7 \%$ (Kazenergy 2019, p. 117). The South zone is dependent on the North zone and receives electricity from it via three transmission lines with a total carrying capacity of $2 \mathrm{GW}$. The South zone includes the oblasts of Almaty, Zhambyl, Kyzylorda and Turkestan, and the cities of Almaty and Shymkent. In 2018, electricity consumption in the South energy zone exceeded in-region energy production on two occasions. The South zone currently has a 11.1 billion kWh electricity generation deficit (Kazenergy 2019, p. 115). By 2020, this deficit is likely to increase by 1,657 MW, according to the Ministry of Energy (Order of the Minister of Energy of the Republic of

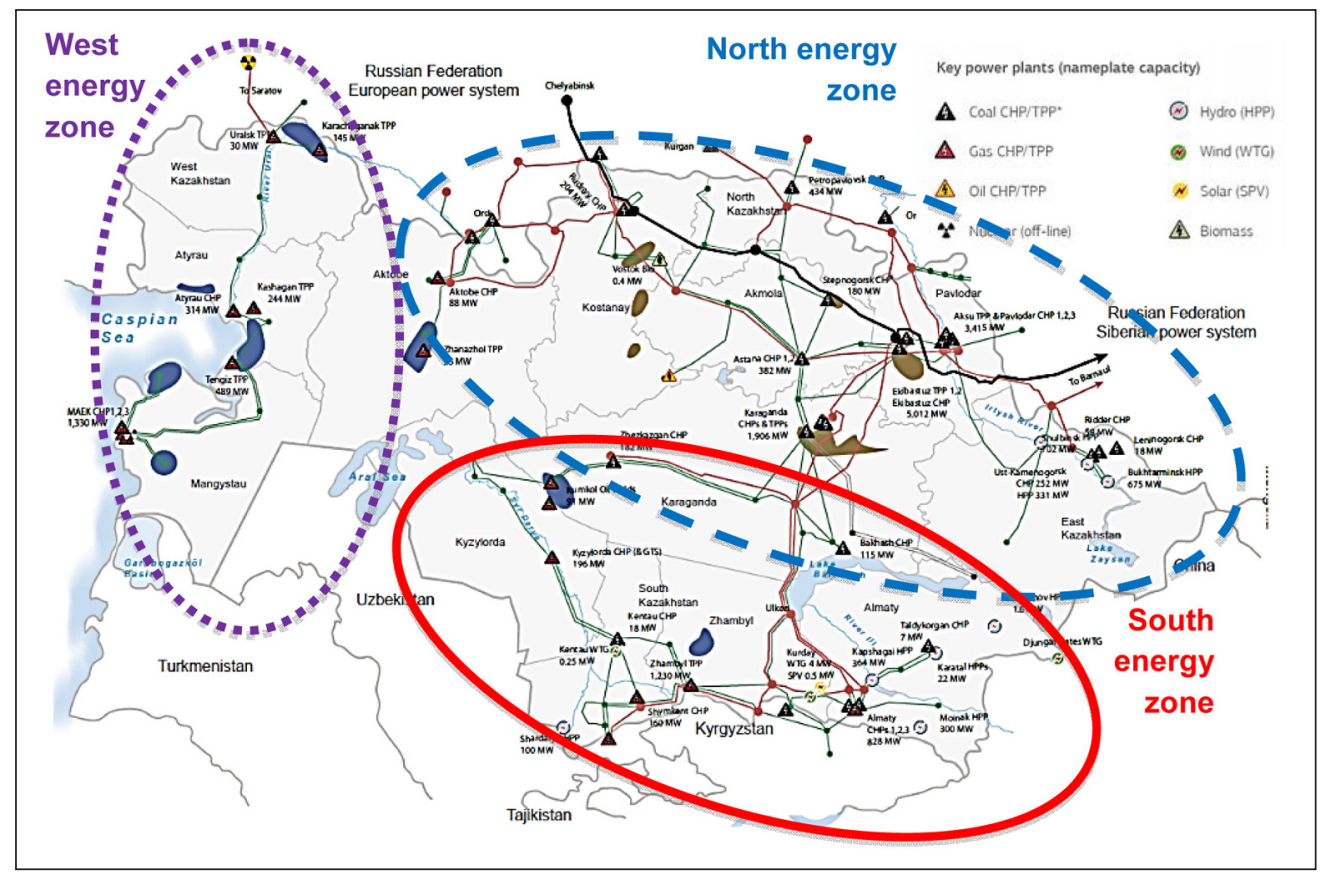

Figure 1: The main energy zones of Kazakhstan.

Source: Developed by authors based on a map taken from Kazenergy, 2015, p. 275. 
Kazakhstan No. 478, 2016). At the same time, the largest share of renewable energy generation (72.5\%) is concentrated in the South zone (KEGOC 2020). We selected the Almaty region of the South zone as our study focus area because it has favourable climate conditions for the development of renewable energy production.

Overall, Kazakhstan offers good conditions for the development of renewable energy, with estimated potential reserves of 920 billion kWh/year of wind energy, 62 billion kWh/year of hydro energy and 2.5 billion kWh/year of solar energy (USAID, 2018, p. 9). However, the share of 'clean' electricity in Kazakhstan is currently only $29.6 \%$ of the total produced, and includes $19.4 \%$ generated using natural gas, $9.7 \%$ produced by hydropower plants, $0.2 \%$ produced by wind plants and $0.1 \%$ produced by solar plants (Kazenergy, 2019, p. 117). Due to government policy supporting renewables, the country is experiencing fast growth of renewable power plants. From 2016 to 2019, the total capacity of renewable power plants increased threefold, reaching $935 \mathrm{MW}$; this means that the country is well on track to reach its 2025 capacity goals (see Table 3). Over the same period, the capacity of solar power plants increased almost eight times, to $450 \mathrm{MW}$, meaning that this is also well on the way to reaching the 2025 goals.

To implement the national renewable energy policy, the government of the Almaty region has ambitious plans to increase the share of renewable energy inputs into total power production from 28\% in 2018 to 60\% in 2025 (Department of Energy and Housing and Communal Services of Almaty Region, 2016). The Almaty region plans to commission 46 renewable power plants with a total capacity of 2,512 MW, accounting for almost $99 \%$ of the country's planned total capacity in renewables in 2025 (see Table 3) and making it the primary destination for most of the commissioned renewable energy plants in Kazakhstan. By 2019, the total installed capacity of renewable power plants in the Almaty Region had reached $606 \mathrm{MW}$ (see Table 4). The total installed capacity of small hydropower plants was $126 \mathrm{MW}$, accounting for $62 \%$ of the national total; the capacity of wind power plants was $223 \mathrm{MW}, 79 \%$ of the national total; and the capacity of solar power plants was $257 \mathrm{MW}$, or $57 \%$ of the national total.

The integration of renewable energy production into the regional power system of the Almaty region is important because the region is experiencing a rising energy deficit. About $40 \%$ of its electricity is currently imported from neighbouring regions of Kazakhstan and Kyrgyzstan. During the winter of 2017-2018, the Almaty region reached a peak load of 532 MW; only $63 \%$ of this load could be produced locally, necessitating imports of $37 \%$ from Kyrgyzstan and traditional coal-based power plants located in the South and North energy zones (Zhambyl GRES, Ekibastuz GRES-1 and GRES-2) (Local civil servants, personal communication, August 2019, Taldykorgan). According to recent estimations, by 2022 the energy deficit in the Almaty region may reach more than $500 \mathrm{MW}$.

Table 3: Installed capacity of renewable power plants in 2016 and 2019, in MW.

\begin{tabular}{lrrr} 
& $\mathbf{2 0 1 6}$ & $\mathbf{2 0 1 9}$ & Planned by $\mathbf{2 0 2 5}$ \\
\hline Total & 295 & 935 & 2,519 \\
Wind power plants & 98 & 282 & 1,200 \\
Solar power plants & 57 & 450 & 1,100 \\
Small hydropower plants & 140 & 203 & 219
\end{tabular}

Source: Developed by the authors based on data retrieved from the Ministry of Energy of the Republic of Kazakhstan (2020) and Kazenergy (2019). 
Table 4: Renewable power plants in the Almaty region, 2019.

\begin{tabular}{|c|c|c|c|}
\hline Name & Location & $\begin{array}{l}\text { Installed capacity, } \\
\text { in MW }\end{array}$ & $\begin{array}{c}\text { Year of } \\
\text { installation }\end{array}$ \\
\hline \multicolumn{4}{|c|}{ Small hydropower plants with total capacity of $126 \mathrm{MW}$} \\
\hline Talgar & Talgar city & 3.2 & 2019 \\
\hline Issyk 1 & Enbekshikazakh district & 4.95 & 2018 \\
\hline Kora 1 & Eskeldinskiy district & 28.5 & 2017 \\
\hline Shelek 1,2 & $\begin{array}{l}\text { Enbekshikazakh district, } \\
\text { Raiymbek district }\end{array}$ & - & 2017 \\
\hline Almaty cascade 10 & Large and Small Almaty river & 46.9 & 2016 \\
\hline Lepsy-2 & Sarkand district & 17 & 2016 \\
\hline Turgen & Enbekshikazakh district & 1.4 & 2016 \\
\hline Verhne-Baskan 1 & Sarkand district & 4.2 & 2015 \\
\hline Sarkand-2 & Sarkand village & 2 & 2013 \\
\hline Issyk-3 & Enbekshikazakh district & 0.98 & 2013 \\
\hline Karatal-2,3,4 & Eskeldy district, Karatal village & 12.0 & 2010 \\
\hline Issyk-2 & Enbekshikazakh district & 5.1 & 2009 \\
\hline \multicolumn{4}{|c|}{ Wind power stations with total capacity of $223 \mathrm{MW}$} \\
\hline Shelek & Enbekshikazakh district & 200 & 2019 \\
\hline Sarybulak & Kapshagai city & 4.5 & 2019 \\
\hline Sarybulak-2 & Kapshagai city & 4.5 & 2019 \\
\hline Kerbulak & Kapshagai city & 4.5 & 2019 \\
\hline Shelek-1 & Enbekshikazakh district & unknown & 2016 \\
\hline Kapshagai 1 & Kapshagai city & 4.5 & 2016 \\
\hline Nurly & Eskeldinskiy district & 4.5 & 2016 \\
\hline Saikan & Zhungar gates & unknown & 2015 \\
\hline \multicolumn{4}{|c|}{ Solar power stations with total capacity of $257 \mathrm{MW}$} \\
\hline Nurgisa & Kapshagai city & 100 & 2019 \\
\hline Unnamed & Zhambyl district & 100 & 2017 \\
\hline Unnamed & Kapshagay city & 0.4 & 2017 \\
\hline Kapshagai 2 & Kapshagai city & 50 & 2016 \\
\hline Unnamed & Talgar district & 5 & 2015 \\
\hline Kapshagai 1 & Kapshagai city & 2 & 2013 \\
\hline
\end{tabular}

Source: Developed by the authors based on data taken from KEGOC (2020), the Central Asia DataGathering and Analysis Team (2019) and the Department of Energy and Housing and Communal Services of Almaty Region (2020). 
This energy deficit increases electricity costs, which negatively impacts the business and investment environment of the Almaty region (Members of the Almaty regional branch of the National Chamber of Entrepreneurs ATAMEKEN, personal communication, May 2018, Taldykorgan). According to a recent 'Doing Business' study, the Almaty region ranks very low (11 out of 16) on the 'getting electricity' indicator, that, among other things, measures the reliability of electricity supply to users (World Bank, 2019). In 2018, the average cost of electricity ${ }^{3}$ in the Almaty region was KZT 17 per 1 kWh (USD 0.045), two times higher than in the Atyrau region (KZT 7 per $1 \mathrm{kWh}$, or USD 0.02), according to the Committee for Regulation of Natural Monopolies, Protection of Competition and Consumer Rights (2019). In Kazakhstan, household consumers are partially protected from rising costs by the regulation of energy consumption tariffs. Nevertheless, the tariff for residents in the Almaty region can increase from KZT 12.95 per $1 \mathrm{kWh}$ (USD 0.034) to KZT 19.65 per $1 \mathrm{kWh}$ (USD 0.051) if a household exceeds the allowed consumption of $130 \mathrm{kWh}$ per month. ${ }^{4}$ Public entities in the Almaty region pay 21.26 KZT per 1 kWh (USD 0.056), and private enterprises pay KZT 20.15 per $1 \mathrm{kWh}$ (USD 0.053).

According to regional development policy, some districts of the Almaty region were included in the Almaty urban agglomeration which was planned to serve as a driver of the country's economic development (Government Resolution of the Republic of Kazakhstan No. $728,2014)$. However, energy deficits and high energy prices are key obstacles to the sustainable development of the Almaty urban agglomeration. It is also unlikely that planned increases in renewable electricity production will substantially reduce the regional energy deficit (National energy experts, personal communication, May 2018, Almaty). The concentration of renewable projects in the region does not achieve the aims of regional development because of the established system of compulsory integration of renewables into the centralized power grid. In many cases, investors express interest in being located close to renewable energy stations, but their enthusiasm decreases when they learn that their energy needs cannot be directly served by renewable power plants (Local civil servants, personal communication, August 2018, Kapshagay).

\section{Renewable Energy Production and the Sustainability of Kazakhstan's National and Regional Energy Systems}

Current regulations do not allow decentralized consumption of clean energy. Renewable energy producers must integrate their output into the centralized electricity supply system. KEGOC is a national company (a subsidiary of the Samruk-Kazyna Sovereign Welfare Fund) which holds a monopoly over the national power grid system and is responsible for dispatching and balancing the national electric power market system. KEGOC established the Financial Settlement Centre for Renewable Energy Sources Support (hereinafter FSC) for centralized purchase and sales of electricity generated by renewable energy sources.

\footnotetext{
${ }^{3}$ According to the current model of the electricity market of Kazakhstan, electricity tariffs for end users consist of the electricity tariff of power plants, the tariff for transmission through the electric networks of KEGOC, the tariff for transmission through the distribution networks of regional electric grid companies, and the charges of regulated electricity suppliers.

${ }^{4}$ Retail tariffs are complex and differ significantly depending on the region, consumer category, time and volume of consumption. For the population, there is a simple two-part pricing system, depending on the time of consumption (day and night tariffs), for legal entities, three-part pricing applies (with the addition of peak tariffs). The Committee on Regulation of Natural Monopolies, Protection of Competition and Consumer Rights of the Ministry of National Economy of the Republic of Kazakhstan approves the prices and tariffs for electricity (Law No. 204-VI ZRK, December 27, 2018).
} 


\section{The Energy Market of Kazakhstan}

In 2009, the government enacted the Law on Support for the Use of Renewable Energy Sources (hereinafter, the RES law). The RES law introduced 15-year tariff stability guarantees, guaranteed purchase of all electricity generated, and guaranteed connections and access to the national supply network and exemption from service fees for electricity transmission (Kazenergy, 2019, p. 138). To create incentives for investors to develop the renewable energy sector, the government accorded renewable energy producers the right to sell electric power centrally via the FSC at fixed feed-in-tariffs that are higher than the tariffs for traditional energy (RES Law, Article 7.1, 2009). The tariffs were established for solar plants at KZT 34.61 (USD 0.09)/kWh; for bio plants at KZT 32.23 (USD 0.084)/kWh; and for wind plants at KZT 22.68 (USD 0.059)/kWh. The feed-in-tariff measure did not work very well, because insufficient attention was paid to the need for tariff flexibility in response to adjustments in the levels of inflation and the fluctuation of the value of the local currency in relation to the US dollar. In 2013, the government approved an Action Plan for the Development of Alternative and Renewable Energy 2013-2020. In 2014, the government established fixed tariffs and introduced annual indexation of fixed tariffs (Government Resolution of the Republic of Kazakhstan No. 271, 2014). Then, in 2017, the government revised the tariff indexation to fix the exchange rate at 70\% for inflation and 30\% for foreign currency (Government Resolution of the Republic of Kazakhstan No. 925, 2017). Annual increases in the fixed tariffs increased the financial burden of the government subsidization of electricity purchases from renewable energy sources (Table 5).

In 2018, aiming to decrease the established tariffs, the government introduced an open auction system (USAID, 2018, p. 14). The auction system replaced the system of feed-in-tariffs. The selection of winners based on the lowest cost allowed the government to achieve the desired decreases in the tariffs for renewable energy purchases. The first 10 auctions for renewable energy projects in Kazakhstan were held in 2018, for projects offering a total capacity of $245 \mathrm{MW}$. The tariff was reduced to $23 \%$ for wind energy, $27 \%$ for solar energy and $27 \%$ for hydro energy (see Table 5). The practice of holding auctions to select renewable energy projects was adopted by the Kazakhstan government as a trending global approach to tendering renewable energy projects in the United States, India and Chile (World Energy Council 2016). However, in the case of Kazakhstan, auctions remain constrained by the underdevelopment of regional power system capacities. Therefore, the Ministry of Energy, in consultation with KEGOC, had to regulate the quantity of renewable energy eligible for support

Table 5: Indexed tariffs for electricity produced by renewable power plants in KZT per $1 \mathrm{kWh}$.

\begin{tabular}{|c|c|c|c|c|c|c|}
\hline \multirow[t]{2}{*}{ Types of RES } & \multirow{2}{*}{$\begin{array}{l}\text { Approved } \\
\text { fixed } \\
\text { tariffs }\end{array}$} & \multicolumn{3}{|c|}{ Indexed tariffs } & \multirow{2}{*}{$\begin{array}{c}\text { Average maxi- } \\
\text { mum auction } \\
\text { price for } 2019 \text {, } \\
\mathrm{KZT} / \mathrm{kW} / \mathrm{h}\end{array}$} & \multirow{2}{*}{$\begin{array}{l}\text { Reduction of the } \\
\text { tariff in } \%\end{array}$} \\
\hline & & 2017 & 2018 & 2019 & & \\
\hline $\begin{array}{l}\text { Wind power } \\
\text { plant }\end{array}$ & 23 & 26 & 28 & 30 & 23 & 23 \\
\hline $\begin{array}{l}\text { Solar power } \\
\text { plant }\end{array}$ & 35 & 40 & 43 & 46 & 29 & 37 \\
\hline $\begin{array}{l}\text { Hydropower } \\
\text { plant }\end{array}$ & 17 & 20 & 21 & 22 & 16 & 27 \\
\hline
\end{tabular}

Source: Developed by the authors based on statistics provided by KOREM (2019), Government Resolution of the Republic of Kazakhstan No.271 (2014) and Government Resolution of the Republic of Kazakhstan No.925 (2017). 
by different energy zones; only then could bidders submit bids to KOREM (the Kazakhstan Electricity and Power Market Operator) (Civil servants from the Ministry of Energy, personal communication, February 2019, Nur-Sultan).

In the case of Kazakhstan, the actual financial burden of the adjusted tariffs is not paid by the government or end-users, but by traditional power plants that are obliged by law to buy electricity from the FSC at the established prices. The FSC serves as the only mediator, buying clean energy and selling it to so-called 'conditional consumers' (RES Law, Article 7.1, 2009), (see Figure 2). In the case of the Almaty region, conditional consumers are traditional power plants, which means they are obliged to buy at least an established amount of electricity generated by all renewable power plants at the high tariffs established by the government. According to Kazenergy's (2019) estimations, today's electricity purchases from renewable power plants account for around $2-4.5 \%$ of total traditional power plant expenditures, but with growth in the renewable sector, they are expected to increase to 15-30\% by 2021 (p. 142). In the long run, this extra financial burden from renewables will result in lower profits for traditional plants, likely resulting in reductions in their expenditures on capital investment.

Energy market regulation slanted towards the interests of renewable energy producers creates non-competitive conditions for the sale of energy overall, ultimately affecting end consumers negatively. In many countries whose national policies support the development of renewables, producers of renewable energy are exempt from the costs associated with energy transmission and the maintenance of electrical networks, so electricity transmission costs are distributed among traditional energy producers. However, in other countries, traditional power plants that buy renewable energy usually pass on the marginal costs of energy transmission and equipment maintenance to the end consumers. In Kazakhstan, this is not allowed; electricity tariffs remain subject to national regulations. In 2009, the government introduced a system of maximum tariffs so that traditional power plants could accumulate the investments necessary to modernize their equipment (Kazenergy 2019). However, this was a partial measure that did not motivate traditional power generators to update their equipment by introducing energy-saving and environmentally friendly technologies.

The Kazakh energy market is undergoing continuous transformation. There is a wholesale energy market in Kazakhstan, where large energy consumers and energy supply companies can buy electricity from generating companies based on bilateral agreements. Until $2019,75 \%$ of the electricity was sold under direct contracts between energy producers and wholesale consumers. In 2019, Kazakhstan switched to a capacity market system that allows equitable distribution of the costs of new generation, expansion, and the modernization of

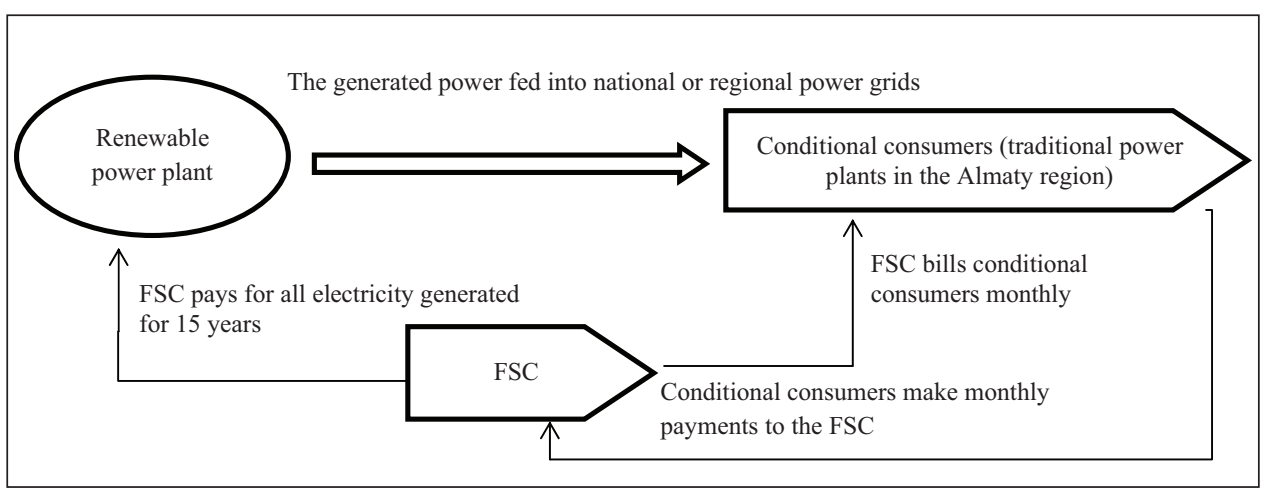

Figure 2: Main players in the renewable energy consumption market. Source: Developed by the authors based on data taken from FSC (2019). 
power plants among all consumers (Kazenergy, 2019). However, the capacity market is not supported by any mechanism for stimulation of technological improvements for outdated assets that do not comply with the country's green economy policy (Kazenergy 2019, p. 136) Furthermore, the marginal capacity tariff does not allow an existing power plant to increase its profits, while the capacity market fails to stimulate the modernization of traditional power plants or the construction of new ones. These problems make it difficult to balance the energy supply with increasing renewable energy inputs without the help of flexible traditional electricity generation sources. In fact, however, renewable production capacity is not even considered in the national demand projections; $90 \%$ of current renewable generation is from solar and wind plants, with an assumed capacity of zero (Kazenergy, 2019, p. 132), because solar and wind power plants cannot guarantee power generation during hours of maximum load.

\section{The integration of renewable power plants into the national and regional power grids of Kazakhstan}

Ideally, the integration of renewable power plants into the existing energy grid should drive the development of a more complex hybrid energy system that uses smart technologies to make electricity distribution more efficient and sustainable (Aldayarov et al. 2017, p. 34). In practice, however, connecting renewable power producers in Kazakhstan into existing power grid brings with it many challenges that have not yet been addressed by government energy policy. There are no specific rules for connecting renewable power plants to regional grids in the Grid Rules 2014 (Aldayarov et al. 2017, p. 35). Traditional energy producers facing increasing energy losses are not well prepared to integrate the variable and unpredictable amounts of extra energy generated by renewable power plants (Kazenergy, 2019). Traditional power plants operating on hydrocarbon resources continue to play a major role in national energy production. According to Kazenergy (2019), 70.4\% of all electricity is still generated from coal. However, the traditional power generation plants inherited from Soviet times are ageing, with $36 \%$ of the steam turbines in thermal power plants at $75 \%$ of their total estimated functional lifetimes (Kazenergy 2019, p. 144). By 1 January 2018, most of the thermal and hydropower plants remaining from Soviet times had been in operation for over 30 years, which is the usual period of operation for such plants (Kazenergy 2017, p. 238). Plants exceeding optimal operation periods experience increases in energy losses and overuse of fuel, and generate more air pollution. The equipment also becomes more prone to accidental damage that can lead to unexpected energy interruptions.

The current electrical network infrastructure of the Almaty region is ageing. It was mainly built in the Soviet era as an integral part of a highly centralized power grid designed to meet the needs of large-scale industry through the development of large energy producers. For example, the Kapshagay hydropower plant, with a capacity of $364 \mathrm{MW}$, located on the artificially created Kapshagay water reservoir with a 28.14 billion $\mathrm{m}^{3}$ water volume, was commissioned in 1970 and still operates using much of its 50-year-old infrastructure. The Almaty region is incapable of integrating renewable energy without considerable public investment in upgrades to its infrastructure, including the renovation and maintenance of switching devices, high-voltage equipment, new current-limiting devices and more (National energy experts, personal communication, May 2018, Almaty). The grid infrastructure needs to be adjusted to renewables to protect grid equipment such as transformers from overloading. As the experience of other countries has shown, penetration of renewable energy production into an existing grid is a difficult task, and one which carries considerable costs for existing regional energy suppliers, given the high level of variability of the renewable energy supply (Barros, Gil-Alana \& Payne 2013). The energy production of solar-, wind- and hydro-power 
plants depends on weather conditions which cannot be predicted with high levels of accuracy in Kazakhstan. ${ }^{5}$

The introduction of small hydropower plants into the Almaty regional grid has already begun to increase excess energy in the system, which negatively impacts some important equipment such as protection devices. For example, in the case of the Tekeli sub-region, which has a concentration of seven small hydropower plants and a single thermal power plant, there is a predicted summer increase in voltage on the generator fuses. This increase of short-circuit currents will likely result in the overloading of transformers, which in the case of the new small hydropower plants will lead in turn to the misfunctioning of protection devices (switches and fuses), thus requiring them to be replaced (Local energy experts, personal communication, April 2019).

Too few periods of relative inertia in the regional power system result in energy surges within the regional power grid. This is because there is only one traditional thermal power plant in the node which has regulatory capabilities and enough periods of inertia. The renewable power generators, including small hydropower plants, are not able to change or maintain production frequency because they do not have rotor speed controllers (National energy experts, personal communication, May 2018, Almaty). To some extent, the integration of renewable energy producers into the regional grid makes them dependent on the production of traditional thermal power plants. Electricity generated by the new renewable power plants increases pressure on the equipment of the traditional plants. (Local energy experts, personal communication, April 2019, Taldykorgan). Due to the lack of energy reserves and plants capable of flexible production, the electricity network of the Tekeli sub-region of the Almaty region is relatively inflexible and vulnerable to fluctuations in the stability of the power system.

In the case of Kazakhstan, both renewable and traditional power plants play a role in the integrated national power system. Due to the unstable nature of energy generation at the solar and wind power plants, the national system needs traditional power plants to balance electricity production. Therefore, ongoing development of renewable power plants requires that policymakers pay attention to the impact of renewable energy policies on the financial and technological sustainability of the overall system of electricity production. The unreadiness of power systems for fluctuations in supply can lead to increases in emergency shutdowns, short circuits and power interruptions. In the case of the Almaty region, unstable functioning of the energy supply may negatively impact local businesses, which are already impacted by rising electricity prices. To avoid disruption to the energy supply, a certain amount of public investment should be directed towards installing modern emergency control and regulation systems that can preserve reliable frequency and voltage flows. There is an urgent need for investment in the modernization of existing traditional plants, which act as the frequency and power regulators of the regional power grid networks.

\section{Energy management in Kazakhstan and the Almaty region}

In Kazakhstan, there is centralized and mainly manual management of the electricity distribution process, which makes it difficult to sustain the stability of the electricity supply. The low level of automation means that the decision-making process is highly dependent on human factors, including the professional competence of the experts responsible. There is a

\footnotetext{
${ }^{5}$ Atlases for both wind and solar power were produced 10 years ago to inform potential investors of the best locations to build new renewable energy plants. However, there is no interactive decision support system for renewable plant operators, containing up-to-date information about weather conditions, that can be used to accurately predict changes in expected weather conditions.
} 
shortage of energy experts who are knowledgeable about the efficient integration of renewable energy inputs into the regional energy network (Managers of traditional and renewable power plants, personal communication, February 2019, Taldykorgan). The complex top-down management of the Kazakh energy system does not allow quick or flexible reactions to changing electricity production and consumption profiles in the regions of Kazakhstan.

Energy management is carried out mainly at a national level, assisted by regional branches (Representatives of the KEGOC, personal communication, February 2019, Nur-Sultan). There is a hierarchical dispatch system of management - the Unified Energy System of Kazakhstan, mainly run by the National Dispatch Centre of the system operator KEGOC, that works with regional dispatch centres. Meanwhile, the regional electricity grid companies (REC) work with the dispatch centres of power grid companies, and the control centres of power plants and electrical network enterprises. The system operator KEGOC, located in Nur-Sultan, manages the production, consumption and transmission of electrical energy. It also controls the balance of electricity supply in the Unified Energy System, based on daily schedules. The system operator uses nationally and regionally available electric power reserves to maintain the balance of electricity supply in the Unified Energy System and the average daily values of electricity flows (Representatives of the Almaty REC, personal communication, February 2019, Taldykorgan).

In Kazakhstan, energy dispatches take place one day in advance of delivery, not hourly as in the USA, Germany and Austria, which all have a higher degree of renewable energy penetration. This day-ahead dispatching is not sufficient to allow for adjustments to the generation schedule or the required load portfolio - caused, for example, by high fluctuations of renewable production occurring during a day. Energy production companies (owners of regional hydroelectric power plants), heat and power plants and renewable energy facilities must report their electricity production volumes to regional energy transmission companies daily (Representatives of the Almaty REC, personal communication, February 2019, Taldykorgan). For example, in the Almaty region, the power transmission company Karatal-Transit LLP is responsible for the power supply network of the Cascade of Karatal hydropower plants (HPP), due to their being located in its operating area. The United Dispatch Centre of Karatal-Transit LLP receives telephone reports from the hydropower plants along with their daily energy generation schedules. ${ }^{6}$ Every morning, the United Dispatch Centre sends all information collected from the energy producers located within its operational area via telephone to the Almaty regional dispatch centre (Representatives of the Almaty REC, personal communication, February 2019, Taldykorgan).

Kazakhstan's current energy management plan aims to preserve the integrity of the national power system, but it does not consider specific regional factors such as how decentralized energy production and variations in supply impact the local energy balance. Nur-Sultan's centralized energy management does not allow Almaty's regional players a sufficient voice in the decision-making process of adapting the national regional energy systems to new renewable energy generation. Regional representatives must follow all managerial instructions coming from Nur-Sultan even when their execution of top-down tasks may lead to serious disruptions in the operation of the regional energy system. Thus regional players are absorbing significant economic and technological costs related to the integration of renewable energy producers. Overall, Kazakhstan currently lacks adequate infrastructure to balance its power

\footnotetext{
${ }^{6}$ Operational control of the consumption of electrical energy in the regions is carried out independently by the dispatch centers of energy transmitting organizations and regional dispatch centres, due to the correction in frequency.
} 
supply on the regional level. Rapid increases in renewable energy inputs create serious challenges for energy management operators that cannot be solved simply by the introduction of smart-grid systems or using traditional plants as regulators.

\section{Conclusion}

The policy directions selected by the national government of Kazakhstan to support renewable energy production pose a significant risk to the sustainable development of the national and regional power systems of the country. There is need for a better energy policy that includes measures not only to promote the construction of renewable power plants, but also to modernize existing traditional power plants and power grids. The overall aim of the national energy policy should be the sustainability of the national and regional power systems. There is a need for a comprehensive analysis of the benefits and drawbacks of integrating renewables into the centrally managed regional energy system. The current policies supporting renewable energy should not come at a serious cost to traditional power producers, regional industries or end-consumers.

The narrow focus on renewable energy generation without adequate investment to modernize regional grid systems and traditional power producers can lead to serious instability in the functioning of national and regional power systems. Intermittent sources of power such as wind and solar energy create challenges for the existing grids and the capacity of traditional power plants to accept and store excess energy. National power system development is complicated by the reliance on ageing generation and transmission infrastructure dating back to the Soviet era. There are regional imbalances in power generation, with the Southern energy zone experiencing a growing deficit. Increasing the share of variable generation from renewable power plants may lead to significant transformations of the energy system of the Almaty region. The recent introduction of renewable energy producers into the regional energy network of the Almaty region has started to force critical technological and economic issues for the sustainability of locally available generating assets.

It is important to apply evidence-based decision-making techniques and to develop policy actions based on the results of a comprehensive assessment of how regional power systems will react to the integration of renewable energy inputs. The effective integration of new renewable energy sources will require a thorough assessment of existing regional energy systems, taking into consideration not only benefits, but also costs. It is important for energy planning and management approaches to consider the differences between the working regimes of traditional and renewable power plants. Planning for power system upgrades should start from analysis of the characteristics of power plants in terms of their capacity to bear extra loads and the availability of energy generation resources, as well as the technical and economic characteristics of their equipment.

The current public investment in the energy sector of Kazakhstan should be re-assessed, with more attention paid to regional development needs. It is important to consider all the possible impacts that can be associated with new renewable energy inputs. The special preassessment of energy reforms should be based on a comparison of the expected short-term and long-term environmental benefits against associated social and economic costs. Under the current system of centralized management and distribution of electricity, renewable energy inputs cannot succeed in facilitating regional economic development in Kazakhstan. Policymakers should explore opportunities for the decentralization of renewable energy production, distribution and consumption, which may help to decrease the unnecessary costs associated with their integration into the traditional centralized energy system of Kazakhstan. 


\section{Competing Interests}

The authors have no competing interests to declare.

\section{Author Information}

Nazym Temirgaliyeva is DAAD scholarship holder and studies Energy and Environmental Management at Europa-University in Flensburg (Germany). Nazym has a Bachelors and a Masters in Power Engineering from Tomsk Polytechnic University (Russia). She works for the regional energy company Infraenergo LLC as an Electrical Engineer.

Madina Junussova is a Research Fellow at the Institute of Public Policy and Administration of the University of Central Asia, Kazakhstan/Kyrgyzstan/Tajikistan and a CERGE-EI Foundation Teaching Fellow. She holds PhD in Public Policy obtained at the School of Public Policy and Administration of Carleton University, Canada. Her research interests include local and regional economic development, rational use of local resources, governance and sustainability.

\section{References}

Abayev, Aidos, Bauyrzhan Yessengeldin, Diana Sitenko, and Yerbolsyn Akbayev. 2018. Possibilities of Solar Energy Utilization for the Development of Rural Areas of the Republic of Kazakhstan. International Journal of Energy Economics and Policy, 8(2): 89-94.

Akhmetov, A., Y. Uchiyama, and K. Okajima. 2011. Wind Power Development in Kazakhstan: Potential and Obstacles. Conference Paper, Conference: The International Conference on Electrical Engineering 2011 (ICEE 2011). Available at https://www.researchgate.net/publication/226570227_Wind_Power_Development_in_Kazakhstan_Potential_and_Obstacles.

Aldayarov, M., I. Dobozi, and T. Nikolakakis. 2017. Stuck in Transition: Reform Experiences and Challenges Ahead in the Kazakhstan Power Sector. Washington, DC: International Bank for Reconstruction and Development/The World Bank. DOI: https://doi.org/10.1596/978-14648-0971-2

Alsaif, Abdulhakim K. 2017. Challenges and Benefits of Integrating the Renewable Energy Technologies into the AC Power System Grid. American Journal of Engineering Research, 6(4): 95-100.

Barros, Carlos P., Luis A. Gil-Alana, and James E. Payne. 2013. US Disaggregated Renewable Energy Consumption: Persistence and Long Memory Behavior. Energy Economics, 40: 425-32. DOI: https://doi.org/10.1016/j.eneco.2013.07.018

Bolyssov, Tokhtar, Bauyrzhan Yessengeldin, Gulvira Akybayeva, Zamzagul Sultanova, and Azamat Zhanseitov. 2019. Features of the Use of Renewable Energy Sources in Agriculture. International Journal of Energy Economics and Policy, 9(4): 363-68. DOI: https://doi.org/10.32479/ijeep.7443

Central Asia Data-Gathering, and Analysis Team. 2019. Wind Power, Hydropower, and Solar Power Potential of the Central Asian Countries. Data Review 17, 18, 19. Retrieved 10 January 2020 from: http://osce-academy.net/en/research/cadgat/.

Committee for Regulation of Natural Monopolies, Protection of Competition and Consumer Rights. 2019. Data on Electricity Tariffs. Retrieved from the official website of the Ministry of National Economy of the Republic of Kazakhstan: http://www.kremzk.gov.kz/rus/ menu2/tarify_srt.

Department of Energy and Housing and Communal Services of Almaty Region. 2016. Programma razvitiya vozobnovlyayemykh istochnikov energii $v$ Almatinskoy oblasti na 2017-2025 goda [Program for Development of Renewable Energy Sources in the Almaty Region for 2017-2025]. Retrieved from the official website of the Almaty region administration: http://energetika.zhetisu.gov.kz/pages/11/. 
Department of Energy and Housing and Communal Services of Almaty Region. 2020. Information on Existing Renewable Energy Facilities in Almaty Region. Retrieved from the official website of the Almaty region administration: http://energetika.zhetisu.gov.kz/ pages/16.

Eshchanov, Bahtiyor, Alina Abylkasymova, Indra Overland, Daniyar Moldokanov, FarkhodAminjonov, and Roman Vakulchuk. 2019. Hydropower Potential of the Central Asian Countries. Central Asia Regional Data Review, 19: 1-7.

European Commission [EU]. 2020. Renewable Energy Directive. Retrieved from the European Commission official website on 13 January 2020: https://ec.europa.eu/energy/en/topics/renewable-energy/renewable-energy-directive/overview.

Financial Settlement Centre for Renewable Energy Sources Support [FSC]. 2019. Energy Market Operation. Retrieved from: https://rfc.kegoc.kz/page/opisaniye-rynka-moshchnosti-2.

Frankfurt School of Finance and Management. 2018. Global Trends in Renewable Energy Investment. Frankfurt am Main: Frankfurt School-UNEP Centre/BNEF. Retrieved on 7 January 2020 from: http://www.iberglobal.com/files/2018/renewable_trends.pdf.

Gastli, Adel, and Javier S. M. Armendáriz. 2013. Challenges Facing Grid Integration of Renewable Energy in the GCC region. EU-GCR Renew. Energy Policy Expert Workshop, 24-27 November, Abu Dhabi, UAE: Gulf Research Center/Masdar Institute.

Government Resolution of the Republic of Kazakhstan No. 271. (2014, March 27). Pravila opredeleniya fiksirovannykh tarifov i predel'nykh auktsionnykh tsen [Rules for determining fixed tariffs and marginal auction prices]. Retrieved from: https://egov.kz/cms/ru/law/ list/P1400000271.

Government Resolution of the Republic of Kazakhstan No. 728. (2014, June 28). Postanovlenie ob utverzhdenii Programmy razvitia regionov do 2020 goda [Resolution on Approval of Regional Development Programme 2020]. Retrieved from http://online.zakon.kz/ Document/?doc_id=31584094\#pos=29;-284.

Government Resolution of the Republic of Kazakhstan No. 925. (2017, December 29). Novie pravila opredeleniya fiksirovannykh tarifov i predel'nykh auktsionnykh tsen [New rules for determining fixed tariffs and marginal auction prices]. Retrieved from: https://egov.kz/ $\mathrm{cms} / \mathrm{ru} / \mathrm{law} / \mathrm{list} / \mathrm{P} 1400000271$.

Green Climate Fund. 2020. Projects in Kazakhstan. Retrieved on 2 January 2020 from: https:/ / www.greenclimate.fund/projects/fp047.

International Energy Agency [IEA]. 2015. Renewable Energy Integration in Power Grids. IEA ETSAP Technology Brief. Retrieved on 5 May 2019 from: https://europeanpowertogas. com/wp-content/uploads/2018/05/Ngg1uITu.pdf.

Karatayev, Marat, and Michéle L. Clarke. 2016. A Review of Current Energy Systems and Green Energy Potential in Kazakhstan. Renewable and Sustainable Energy Reviews, 55: 491-504. DOI: https://doi.org/10.1016/j.rser.2015.10.078

Karatayev, Marat, Stephen Hall, Yelena Kalyuzhnova, and Michéle L. Clarke. 2016. Renewable Energy Technology Uptake in Kazakhstan: Policy Drivers and Barriers in a Transitional Economy. Renewable and Sustainable Energy Reviews, 66: 120-36. DOI: https://doi. org/10.1016/j.rser.2016.07.057

Kazakhstan Operator of the Market of Electric Energy and Power [KOREM]. 2019. Data on auction results. Retrieved from: https://vie.korem.kz/rus/analitika/resultaty_torgov.

Kazenergy. 2017. The National Energy Report 2017. Astana: Kazakhstan association of oil, gas and energy sector organizations "Kazenergy". Retrieved from: http://www.kazenergy.com.

Kazenergy. 2019. The National Energy Report 2019. Astana: Kazakhstan association of oil, gas and energy sector organizations "Kazenergy". Retrieved from: http://www.kazenergy.com. 
KEGOC. 2020. Data of the system operator of KEGOC JSC for 2016-2020. Retrieved on 12 January 2020 from: https://www.kegoc.kz.

Koch-Ciobotaru, Cosmin, Andoni Saez-de-Ibarra, Egoitz Martinez-Laserna, Daniel-Ioan Stroe, Maciej Swierczynski, and Pedro Rodriguez. 2015. Second Life Battery Energy Storage System for Enhancing Renewable Energy Grid Integration. In 2015 IEEE Energy Conversion Congress and Exposition (ECCE) (pp. 78-84). IEEE. DOI: https://doi.org/10.1109/ ECCE.2015.7309672

Koshim, Asima, Marat Karatayev, Michéle L. Clarke, and William Nock. 2018. Spatial Assessment of the Distribution and Potential of Bioenergy Resources in Kazakhstan. Advances in Geosciences, 45: 217-25. DOI: https://doi.org/10.5194/adgeo-45-217-2018

Law on Natural Monopolies and Regulated Markets No. 272. (1998, July 9). Retrieved from: http://adilet.zan.kz/eng/docs/Z980000272_.

Law on Support for the Use of Renewable Energy Sources No. 165 IV. (2009, July 4) [O podderzhke ispol'zovaniya vozobnovlyayemykh istochnikov energii]. Retrieved from https://online. zakon.kz/Document/?doc_id=30445263.

Law of the Republic of Kazakhstan on Natural Monopolies No. 204-VI. (2018, December 27). Retrieved from: https://cis-legislation.com/document.fwx?rgn=112591.

Lin, Boqiang, and Jianglong Li. 2015. Analyzing Cost of Grid-Connection of Renewable Energy Development in China. Renewable and Sustainable Energy Reviews, 50: 1373-382. DOI: https://doi.org/10.1016/j.rser.2015.04.194

Ministry of Energy of the Republic of Kazakhstan. 2020. Renewable Statistics. Retrieved from: http://energo.gov.kz.

Mouraviev, Nikolai, and Anastasia Koulouri (Eds.). 2018. Energy Security: Policy Challenges and Solutions for Resource Efficiency. Cham: Springer. DOI: https://doi.org/10.1007/9783-030-01033-1

Mukatov, Bekzhan, and Ravil Khabibullin. 2018. Renewable Energy Sources in Future Energy Balance of the Republic of Kazakhstan. EDP Sciences: In E3S Web of Conferences, 58: 03006. DOI: https://doi.org/10.1051/e3sconf/20185803006

Omri, Anis. 2014. An International Literature Survey on Energy-Economic Growth Nexus: Evidence from Country-Specific Studies. Renewable and Sustainable Energy Reviews, 38: 951-9. DOI: https://doi.org/10.1016/j.rser.2014.07.084

Order of the Minister of Energy of the Republic of Kazakhstan No. 210. (2014, December 18). Grid Rules. Retrieved from: https://cis-legislation.com/document.fwx?rgn=77092.

Order of the Minister of Energy of the Republic of Kazakhstan No. 478. (2016, November 7). Ob utverzhdenii prognozov balansa elektroenergii i moshchnosti na 2019-2025 gody. [On approval of electricity and capacity balance forecasts for 2019-2025]. Retrieved from: https://online.zakon.kz/m/document/?doc_id=36988923.

Presidential Executive Decree of the Republic of Kazakhstan No. 577. (2013, May 30). Kontseptsiya po perekhodu Respubliki Kazakhstan k "zelenoy ekonomike» [Concept for the transition of the Republic of Kazakhstan to the "green economy"]. Retrieved from: https://online.zakon.kz/Document/?doc_id=31399596.

Presidential Executive Decree of the Republic of Kazakhstan No. 636. (2018, February 15). Ob utverzhdenii Strategicheskogo plana razvitiya Respubliki Kazakhstan do 2025 goda [Strategic Development Plan of the Republic of Kazakhstan until 2025]. Retrieved from https://online.zakon.kz/document/?doc_id=38490966.

Ruggiero, Salvatore, and Heikki Lehkonen. 2017. Renewable Energy Growth and the Financial Performance of Electric Utilities: A Panel Data Study. Journal of Cleaner Production, 142(4): 3676-88. DOI: https://doi.org/10.1016/j.jclepro.2016.10.100 
Sadorsky, Perry. 2012. Energy Consumption, Output and Trade in South America. Energy Economics, 34(2): 476-88. DOI: https://doi.org/10.1016/j.eneco.2011.12.008

Sarbassov, Yerbol, Aiymgul Kerimray, Diyar Tokmurzin, GianCarlo Tosato, and Rocco De Miglio. 2013. Electricity and Heating System in Kazakhstan: Exploring Energy Efficiency Improvement Paths. Energy Policy, 60: 431-44. DOI: https://doi.org/10.1016/j. enpol.2013.03.012

Tasmaganbetov, Aslan B., Gulnar T. Kunurkulzhayeva, Zauresh O. Imanbayeva, Zhumabay Ataniyazov, and Dinmukhammed N. Shaikin. 2020. Future Development of Price Instruments of State Support for the Use of Renewable Energy Sources in Kazakhstan. International Journal of Energy Economics and Policy, 10(1): 140-44. DOI: https://doi. org/10.32479/ijeep.8481

Teleuyev, Galym B., Oksana V. Akulich, Marsel Andrey Kadyrov, A. Ponomarev, and Elnur L. Hasanov. 2017. Problems of Legal Regulation for Use and Development of Renewable Energy Sources in the Republic of Kazakhstan. International Journal of Energy Economics and Policy, 7(5): 296-301.

Terehovics, Edvins, Asset Khabdullin, Arman Khabdullin, Zauresh Khabdullina, Guldana Khabdullina, Ivars Veidenbergs, and Dagnija Blumberga. 2017. Why Solar Electricity has High Potential for Kazakhstan Industries. Energy Procedia, 113: 417-22. DOI: https://doi. org/10.1016/j.egypro.2017.04.026

USAID. 2018. Rukovodstvo dlya investorov po realizatsii proyektov vozobnovlyayemykh istochnikov energii $v$ Kazakhstane [A Guide for Investors on the Implementation of Renewable Energy Projects in Kazakhstan]. Retrieved from: https://rfc.kegoc.kz/news/detail/rukovodstvo-dlya-investorov-po-realizatsii-proyektov-vozobnovlyayemykh-istochnikov-energii-v-kazakhstane-v-redaktsii-2019-goda.

World Bank. 2019. Doing business in Kazakhstan. Washington, DC: International Bank for Reconstruction and Development/The World Bank. Retrieved from: https://www.doingbusiness.org/content/dam/doingBusiness/media/Subnational-Reports/DB19_KAZ_ Full-report.pdf.

World Energy Council. 2016. Variable Renewables Integration in Electricity Systems: How to Get it Right? World Energy Perspective. Retrieved from: https://www.worldenergy.org.

Yashkov, V. A., A. A. Konarbaeva, and A. I. Ismagulova. 2015. Vetroenergetika kazakhstanaosnovnoy al'ternativnyy istochnik elektroenergii: Tendentsii razvitiya, perspektivy i mify [Wind power of Kazakhstan - the main alternative source of electricity: Development trends, prospects and myths]. Science and World [Nauka i Mir ], 2(19): 112-15.

\footnotetext{
How to cite this article: Temirgaliyeva, Nazym and Madina Junussova. 2020. Renewable Electricity Production and Sustainability of the National and Regional Power Systems of Kazakhstan. Silk Road: A Journal of Eurasian Development 2(1), pp. 35-53. DOl: https://doi.org/10.16997/srjed.15
}

\section{Submitted: 11 June 2019 Accepted: 17 March 2020 Published: 13 May 2020}

Copyright: (c) 2020 The Author(s). This is an open-access article distributed under the terms of the Creative Commons Attribution 4.0 International License (CC-BY 4.0), which permits unrestricted use, distribution, and reproduction in any medium, provided the original author and source are credited. See http://creativecommons.org/licenses/by/4.0/.

WII Silk Road: A Journal of Eurasian Development is a peer-reviewed open access journal published by University of Westminster Press. 